\title{
Local workplace employment and the quality of jobs framework
}

\author{
Paul S. Jones* \\ Sheffield Hallam University
}

\begin{abstract}
There is an increasing recognition that it is quality as much as quantity of employment which is important in assessing the positions and progress of local economies. Not least of all in light of the Lisbon Strategy and Leitch Report which emphasise world class skills and the knowledge economy. The paper details how the so called 'Quality of Jobs' framework can be adapted to local area data to produce consistent estimates of local area 'job quality' through time, based on Census, Annual Population Survey and Labour Force Survey sources. The methodology is described and local area estimates shown for illustration.
\end{abstract}

Keywords: Job quality, knowledge economy, Lisbon strategy, local area, occupations.

\section{Introduction}

Traditional analysis of local employment outcomes has tended to focus on the quantity of employment in the local area/region. In this respect there are two main frameworks of analysis. Firstly, there is the well known 'labour-market accounts' method. This provides an arithmetic framework for assessing the (changing) fortunes of the local economy in terms of numbers employed, unemployed, or economically inactive, as well as accounting for commuting and migration flows and natural changes in population over time. This framework has been adapted to various scenarios including notably for British cities (Turok and Edge, 1999) and in the case of Britain's coalfields (Beatty et al., 2007) and seaside towns (Beatty and Fothergill, 2004). The second approach is based on the concept of 'job deficits'. At the simplest level this quantifies the shortfall in the number of jobs available locally in relation to the number of people seeking those jobs; for example see Erdem and Glyn (2001) and Fothergill (2001). Measuring job deficits also relates closely to the debate around 'hidden unemployment' (see Green, 1999; Green and Owen, 1998). It is also related to the concept of 'job densities' (see ONS, 2003) which measure the ratio of number of jobs (workplace employment) to number of working-age residents at local level. 
With this in mind, it is becoming increasingly recognised that measures of quantity alone might not suffice. When comparing the relative fortunes of local economies it is the quality of jobs locally, as much as quantity, which is important. This is especially true in view of the recent policy focus on 'productivity' differences between local area and regions (see HM Treasury, 2003). Productivity differences reflect the fact that gross value added (GVA) per worker is higher in some areas (for example in London and the South East) primarily due to the fact that industry and occupational structures are favourable and biased towards higher value/more productive employment. In addition, assessing the changing quality profile of jobs may also be important in terms of quantifying the process of job creation and destruction; for example, the extent of local area recovery from industrial decline and the replacement of primary sector employment. In this respect, measures of job quality complement existing quantity based measures such as those developed by Davis, et al. (1996).

In terms of economic policy background, the importance of high quality jobs is now widely acknowledged. The so called "Lisbon Strategy" (a dictate of the meeting of the European Council in Lisbon March 2000) gives an explicit commitment to the transition to a "dynamic and competitive knowledge-based economy", with the themes of high value skills and human capital integral to the programme of commitment to the development of the "learning economy". This European led initiative has been mirrored by developments in UK policy around the championing of the so called "knowledge economy" (see Hepworth et al., 2005) on the back of the influential Leitch Report. Leitch (2006) emphasises the need to develop world class skills, through the provision of better education and training. Leunig and Swaffield (2008) and Athey et al. (2007) make much of the fact that some UK cities have done much better than others in this respect over recent years. Finally, in the same vein, the recent reassessment of the UK's Welfare-to-Work programmes which promote "work first" approaches (see Freud, 2007; Harker, 2006) also emphasise the need for access to high quality employment opportunities for those seeking work.

Coming from a separate perspective, the issue of quality of jobs has emerged as an important subject in the economics literature in light of the effect of technological change on the profile of employment. Evidence suggests that there has been a polarisation of employment during the past decades with larger numbers of highest and lowest quality jobs created but a disappearing middle ground. Evidence of this is presented variously in the USA (for example see: Autor et al., 2003) but also for the UK (see Goos and Manning, 2007; Kaplanis, 2007). This literature is important in the context of this paper since it conceptualises and develops a framework for measuring changes in the profile of job quality. The method proposed by Goos and Manning (2007) has been further developed following Jones and Dickerson (2007) and Jones and Green (2009). The details of the framework and its application to local area data are described in the sections which follow.

It is argued that the introduction of the quality of jobs into the debate regarding local economies enhances the debate and enriches the picture in terms of describing and explaining spatial differences in employment in the vein of Massey (1984). Measuring the profile of jobs based on occupational structure offers an alternative to GVA based measures which, it is argued, are distorted by differences in local income and/or purchasing power and so might not be directly comparable. In practical terms it also helps overcome problems associated with restricted availability of local GVA data, from a geographical perspective and prior to the last decade, so that a longer historical picture is available. 


\section{The Quality of Jobs framework}

The 'Quality of Jobs framework' outlined in this paper follows the economics literature and, as such, has a deliberately narrow focus, with 'job quality' taken as being synonymous with monetary aspects of work. Following this literature 'job quality' is typically reflected in the (relative) average pay in each job, and abstracts from non monetary aspects of work; see Acemoglu (1999) and Goos and Manning (2007) amongst others. It is emphasised that because the measures are based on simple economic assumptions they provide crude and indicative indicators rather than precise measures.

To the non economics specialist this approach may seem rather crude. In particular, there is much work to suggest that what constitutes 'job quality' from the perspective of the individual also includes intangible aspects of employment. These may include: job security, satisfaction, working conditions, flexibility around family commitments, work-related stress and workload, as well as employment rights. Early work by Piore (1975) on labour segmentation into upper and lower tier work acknowledges such factors, as does the literature on the job satisfaction (for example see Jencks et al., 1988; Meisenheimer 1998; and OECD, 2001). To the knowledge of the author, amongst the economics literature, only Gittleman and Howell (1995) attempt to introduce non monetary aspects of employment into their empirical work on job quality, introducing aspects of working conditions, employment status and institutional setting of employment in addition to standard measures of earnings.

Whilst the focus on monetary reward is not without its limitations, it can be justified on theoretical grounds. Firstly, we can suppose that in a market economy the value of a job is equal to the marginal productivity of that job in monetary terms (i.e. as valued by the market), and reflected through sharing of economic surplus or market forces in setting workers' pay. In this respect monetary earnings from employment summed locally will closely mirror gross value added (GVA) which measure the value of output in the local area, as published at NUTS level geography by the Office for National Statistics (ONS). From the perspective of implementing the framework meaningfully at a local area level the monetary value of wealth produced is clearly important and is not unrelated to the policy focus on 'productivity' discussed earlier. Secondly, abstracting from the local area to the individual, it should be emphasised that many of the positive non monetary job characteristics are positively correlated with pay. In particular, there is a wealth of evidence on the health benefits of higher socio economic status (SES) associated with higher income jobs. Cutler et al. (2008) survey literature in this area. Moreover, Sen (1998) views longevity as the key measure of economic success.

Finally, and in addition to theoretical considerations, a strong justification for using remuneration levels as a metric for job quality is one of practicality. Earnings provide an objective and convenient means of comparison. Further, earnings data is readily available from official sources. In contrast, incorporating composite aspects of non monetary rewards would potentially cause great statistical difficulties and problems of data collection.

Having arrived at a measure of quality, the term 'job' is more precisely defined. For the purposes of achieving a workable statistical definition, standard occupation and/or industry classifications are generally used. However, the choice of definition is not immediately clear and there is ongoing debate around whether detailed occupation categories should be used or, alternatively, whether more coarsely defined occupations should be interacted with industry categories to define 'jobs'. The main theoretical justification for the latter approach is that some industries may well be associated with significant wage differentials (so called “Industry wage premia"; see Martins, 2004). 
Early USA papers on 'job quality' tended to use industry-occupation cells to define jobs; for example see Acemoglu (1999), Farber (1997), Ilg (1996), Costrell (1990). However, the seminal UK paper by Goos and Manning (2007) analyses job quality defined using both detailed occupation (Standard Occupational Classification, SOC) and by interaction of occupation with industry (Standard Industrial Classification, SIC). The results of their experiments around job definitions are captured in the following quotation: "the occupation part of our definition is much more important than the industry part...[with] similar results whether a job is defined by occupation alone or by an occupation-industry interaction," (Goos and Manning, 2007). Subsequently, UK based papers have tended to define a job as being synonymous with a single 4-digit unit group using the Standard Occupational Classification (SOC). This is the case in Jones and Green (2009), Jones and Dickerson (2007) and Kaplanis (2007). In addition to simple definitions of 'jobs', as outlined above, more complex schemes have been designed including mapping jobs into categories based on skill-typologies (Autor, et al., 2003) and hierarchical cluster types (Gittleman and Howell, 1995). The enduring point here is that no clear consensus has been achieved on how 'jobs' are best defined and much depends on the context of the analysis and the availability of data, as will be discussed in the next section with regards the local based measures.

In terms of analysing UK data, the Standard Occupational Classification (SOC) provides the recognised standard for classification of occupation, as employed by the Office for National Statistics (ONS). The current system of classification uses the SOC2000 standards which replaced earlier systems of classification including SOC1990 and earlier KOS standards. The system of classification is revised periodically. The SOC2000 system has four hierarchical levels of classification according to level of definition, from the most coarse category Major group (1 digit), through Sub major group (2 digit); Minor group (3 digit); to the finest category of classification: Unit group (4 digit) which provides 353 distinct job categories. The measures discussed in this paper retain maximum information regarding structure of employment. Table 1 lists the (broad) Major groups of SOC for the reader without prior knowledge.

As discussed, industry can also be used to define jobs using occupation-industry combinations. This is an expedient course of action when applying the quality of jobs framework to UK local area data, as detailed below. In this case employment counts are available based on the sections (17 broad groups) of the Standard Industrial Classification (SIC). The classification used in this and previous papers and based on SIC1992 standards, although a revised classification of SIC is now available and, as with SOC, the system is updated periodically. Table 1 also lists the industry sections of SIC1992.

Once jobs are defined, they are then ranked to create an index of quality, according to median earnings. For the UK, this index is typically created using detailed earnings data from the quarterly Labour Force Survey (LFS). Following the standard approach, the median hourly take home pay of all employees within a SOC unit occupation group is calculated. These calculations are done by the individual researcher, in this case the author. The use of the median rather than the (arithmetic) mean as the measure of average pay in the job removes the impact of any skewness within occupation and/or outliers in the observations. Jobs are then ranked from highest to lowest paid (proxy for quality) with the SOC 2000 index going from rank 1 (highest; 1112: Directors and chief executives of major organisations) to rank 353 (lowest; 9226 Leisure and theme park attendants). Rankings are based on Jones and Green (2009). Each occupation thus has a quality index rank. Mapping the percentage of employment into each rank we arrive at a distribution of employment by job rank. 
The ranked distribution can be used to measure changes in employment over time or to compare employment outcomes between locations. The ranked distribution is typically calculated at a particular point in time. Equally, however, this can be repeated at different points in time to compare rankings or to compare the distribution of job quality based on different systems of occupational classification, for example using the earlier SOC1990 classification. Evidence suggests that rankings are highly correlated between regions and over time. Moreover, median hourly earnings are found to vary much more between occupations (i.e. across jobs) rather than within occupations; see Jones and Dickerson (2007). Both these points confirm that the rank index is robust and stable.

Once jobs are ranked in order of quality it is feasible to define cut-off points to define discrete categories of 'high' and 'low' quality jobs. This follows Ilg (1996). Further, following Jones and Dickerson (2007) and Jones and Green (2009), the cut off points may be defined using percentile measures. Broad measures of highest and lowest quality jobs are defined as the top and bottom quartiles $\left(25^{\text {th }}\right.$ and $75^{\text {th }}$ percentile) of the rank distribution of jobs, with 88 jobs in each category, based on SOC2000 unit groups. Narrow measures of highest and lowest quality jobs are defined as the top and bottom deciles $\left(10^{\text {th }}\right.$ and $90^{\text {th }}$ percentile) of the rank distribution of jobs, with 35 jobs in each category, based on SOC2000 unit groups. Although such cut offs are arbitrary they are useful in terms of operationalising the framework. That is, when comparing the profile of jobs in two locations, the task of comparing ranked distributions is reduced to comparing two numbers: percentage of employment in highest and lowest quality categories, whether defined using broad or narrow measures. The robustness of such comparisons can be examined by sensitivity analysis of the results with respect to changes in percentile cut-off points.

\section{Table 1: Broad Occupational and Industrial Classifications}

\begin{tabular}{ll}
\hline STANDARD OCCUPATIONAL CLASSIFICATION (SOC2000) \\
\hline Major Groups & Managers and senior officials \\
1 & Professional occupations \\
3 & Associate professional and technical occupations \\
4 & Administrative and secretarial occupations \\
5 & Skilled trades occupations \\
6 & Personal service occupations \\
7 & Sales and customer service occupations \\
8 & Process, plant and machine operatives \\
9 & Elementary occupation \\
\hline
\end{tabular}




\begin{tabular}{ll}
\hline STANDARD INDUSTRIAL CLASSIFICATION (SIC1992) \\
\hline Sections & \\
A & Agriculture, hunting and forestry \\
B & Fishing \\
C & Mining and Quarrying \\
D & Manufacturing \\
E & Electricity, gas and water supply \\
F & Construction \\
G & Wholesale and Retail Trade including Repairs \\
H & Hotels and restaurants \\
I & Transport, storage and distribution \\
J & Financial intermediation \\
K & Real estate, renting and business activities \\
L & Public administration and defence, social security \\
M & Education \\
N & Health and social work \\
O & Other community, social and personal service activities \\
P & Private households with employed persons \\
Q & Extra-territorial organisations and bodies (e.g. UN, EC, OPEC, etc) \\
\hline
\end{tabular}

\section{Deriving Local Area Estimates}

The derivation of local area estimates for job quality is a further departure from the framework described above, and an area of ongoing research. Local area is used in this paper to refer to Local Authority Districts (LADs)/Unitary Authorities (UAs) in England and Wales. There are 376 such areas. This choice of geography is restricted by availability of data and consistency of geographical unit over time. LAD/UA is the lowest consistent geographical unit which details workplace employment (i.e. rather than resident based employment). Workplace employment is not available at census Ward level. The LAD/UA geography is ideal in terms of providing a picture of (changing) employment in the major towns and cities without the excess detail of lower denomination geography.

The major challenge in implementing the framework at local level is the somewhat limited availability of data on employment by occupation. The UK estimates, described previously, derive rankings using LFS data at detailed SOC unit group. This option is not available for the local area as Government Office Region (GOR) is the lowest unit of geography in the LFS. Local area estimates instead use Census based information (2001, 1991 and 1981 Censuses of England and Wales) as well as the Annual Population Survey (APS) which is available on a quarterly basis after Spring 2005. The Census/APS workplace population counts by occupation vary by time period in terms of the system of classification used and the number of categories available. The problem of limited data is also compounded by the fact that availability of workplace 
employment data from the Census is more limited than is resident based counts of employment. At the most detailed level of analysis, the availability of occupation based data is as follows:

- 2007 Annual Population Survey (APS) data details workplace population by occupation according to SOC2000 Sub-major group, of which there are 25 categories; and according to SOC2000 Major group, of which there are nine categories, when combined with industry

- 2001 census data details workplace population by occupation according to SOC2000 Major group, of which there are nine categories

- 1991 census data details workplace population by occupation according to SOC1990 Sub-major Group, of which there are 22 categories

- 1981 census data details workplace population by occupation according to KOS standard Occupation orders, of which there are 16 categories.

The inconsistent nature of the classifications leaves us with two potential problems from the point of view of implementing the quality of jobs framework. Firstly, there is a question of how to compare changes in quality of jobs over time given the changes in data. Secondly, there is a more serious issue of deriving a ranked distribution of jobs by quality given that there are so few categories of occupation available. The original framework ranks occupations according to 353 job categories based on the most detailed breakdown of SOC. However, this is not available at the local level. Ranking nine (at a minimum) or 25 (at a maximum) occupations is much less satisfactory in that occupation can longer be thought of as satisfactorily mapping to job role. Moreover, a great deal of detail is lost with regard to variation in pay within occupation groups which may impact on the accuracy of the final analysis at the local level. The proposed solution combines occupation data with workplace data on industry of employment (using Standard Industrial Classification, SIC), available in the Census/APS.

Constructing consistent benchmark data for comparison over each period is also problematic. Ideally one would like to observe a matrix of employment by industry and occupation. This is possible, in part, in that the APS and Census 2001 give workplace employment counts on a SIC-SOC matrix, although on reduced dimensions in the case of the APS. Prior to this however, the 1991 and 1981 censuses SIC and SOC counts are available separately but not on a matrix. In addition to this there is a small practical difficulty at local level in that APS data SIC-SOC cell counts may be incomplete since small cell counts are not disclosed by the ONS. This means that the APS SIC-SOC cell counts need ex-ante adjustments to reconcile to local area job totals, although this is trivial in most cases. Finally, changes in classification of SIC/SOC or different aggregation of the data over time means that the dimensions of the SIC-SOC matrices will be different for each period and not directly comparable without further methodological innovation.

These issues are overcome by estimating the percentage of jobs in each SIC-SOC cell which can be classified as high or low quality. This is done, following the quality of jobs framework, using additional information from the LFS at the national level. For each period in question, detailed occupations are ranked in the LFS at national level and cut-off points are applied. Cut-off points for 'high quality' and 'low quality' jobs are defined, as described previously, at percentiles $p$ and 100-p of the ranked distribution, respectively. Secondary matrices are then constructed by cross tabulation of the quarterly LFS dataset(s) to derive the percentage of employment which is high and low quality for each broad based SIC-SOC combination. Applying these percentages to the local SIC-SOC workplace estimates we are able to calculate the estimated number high or low quality jobs in each cell. These are summed to give a final estimate of total 
number of high quality jobs, $H Q_{i}(p)$, and low quality jobs, $L Q_{i}(p)$, i.e. defined for local area $i$ and calculated based on percentile cut-off point $p$, and calculated for each time period.

Using these estimates it is then possible to compare local areas, in terms of the variation of job quality across space, or to make inter temporal comparisons for a given local area. The metric used in order to make these comparisons is the estimated ratio of high to low quality jobs, $\theta_{i}$, within local authority $i$. The ratio acts to normalise local authority counts which will vary according to size of total employment. The measure is termed the local quality index, with the formula is shown below.

$$
\theta_{i}(p)=\frac{H Q_{i}(p)}{L Q_{i}(p)}
$$

Whilst this method can be readily implemented for 2001 Census and APS data, 1991 and 1981 Census data are more problematic since SIC and SOC data is available separately but not on a matrix, as required. In this case the SIC-SOC matrix can be obtained using a RAS (rescaling) procedure, following Stone (1961). This method will provide robust estimates and has been widely applied in economics, particularly in the context of input-output analysis and national income accounting; see Lahr (2004). The RAS procedure is a matrix balancing algorithm which takes an initial information matrix containing information regarding SIC-SOC counts or estimates. The matrix cells are rescaled by row and column iteratively until they sum to required row (workplace occupation) and column (workplace industry) totals. The procedure has been shown to be convergent so that estimates will always be available; see Stone (1961). The better the information in the initial information matrix the more precise the final estimates although any initial information matrix can be used in principle. The obvious choice of initial information in this case is the resident based SIC-SOC employment counts which are available in the 1991 and 1981 census. It is reasonable to suggest that patterns of resident employment (by SIC-SOC) will in part reflect workplace employment in the local area. In fact these two matrices will be identical in the theoretical case where there is an absence of cross-authority commuting flows.

\section{An Example: The City of London}

Since the methodology described is somewhat dense in terms of detail, it is best illustrated using a worked example based on a local area. This makes the calculations visible and will give the reader a clearer feel for how the results are generated. The City of London is chosen as an example, from a potential list of 376 local areas in England and Wales. The City of London is most interesting in terms of the quality of jobs debate. Not only has it been an engine of UK economic growth ever since the 'big bang' of the mid 1980s, but it is also interesting because, despite its small area size, it has a large economy of almost a half a million workplace jobs according to 2007 estimates (with only a few thousand residents). Its economy is highly specialised in banking and finance and other head office related functions with a distinct skew in employment towards high quality jobs that is almost unique in England and Wales. This section compares workplace employment counts for the City of London with England and Wales as a whole based on 2007 APS counts and 2001 Census data. Pre 2001 data is not presented due to constraints of space. Finally, it is noted that the APS data is taken from 2007q1 and effectively pre-dates the onset of the credit crunch which could well distort comparisons. 
Table 2 presents 2007 APS estimates of workplace employment for the City of London and England and Wales. Table 3 similarly shows 2001 Census counts. The tables present employment on a SIC-SOC matrix, with aggregations of SIC differing slightly between 2007 and 2001. Comparing the City of London with England and Wales, the figures reveal that City's employment base has a high degree of employment specialisation in the financial and business sectors of the economy (SIC J and K) with a strong bias towards higher skilled managerial (SOC group 1) and professional (SOC groups 2 and 3) occupations. These two sectors account for the majority of employment (325,000 of 491,000 jobs in 2007 ; compared to 252,000 of 312,000 jobs in 2001) with the vast majority of employment in these sectors in managerial or professional occupations. At the other end of the skills spectrum we see that employment in elementary employment is relatively scarce. Finally we note, comparing 2007 with 2001, a high volume of job creation. During this period, which represents (with hindsight) the expansion of the recent boom years, 179,000 jobs were created in the City, with just short of 2 million jobs being created in England and Wales.

Tables 4 and 5 show, respectively, the percentage of employment in high quality and low quality jobs for SIC-SOC combinations. The tables are divided into two sections. In each case the upper panel shows the organisation of SIC consistent with aggregation of data in the APS. The lower panel of the tables shows additional detail on SIC categories consistent with the 2001 census. These estimates implement the methodology described in the previous section based on ranking of occupations in the LFS. In this instance the rankings are calculated from a large merged LFS file from 2004-07 (as used by Jones and Green, 2009) which contains a base sample more than 123,000 working individuals. The dataset falls conveniently between the two periods and uses SOC2000 standards. The tables show estimates based on two cutoff points using upper and lower quartile (UQ and LQ) and upper and lower decile (UD and LD) of the ranked distribution. Note the distinct correlation of job quality with SOC major group; with higher quality jobs almost exclusively restricted to SOC groups 1-3. Note also the variation of job quality across industries, with the financial and business sectors of the economy (SIC J and K), mentioned previously, being associated with higher quality employment.

Finally, Table 6 summarises information on employment by job quality for the City of London and England and Wales. These figures calculate the number of high quality and low quality jobs for each period, based in turn on quartile and decile measures. The figures are derived from estimates presented in Tables 2-5. The measures capture the distinct upward bias in job quality in the City. A local index value, $\theta$, of greater than 1 represents more high quality than low quality jobs in the local economy. In the City the ratio of high to low quality jobs is in the order of 4 to 1 . Specifically, the 2007 local index $(\theta)$ measure shows a value of 4.08 for the City (falling from 5.87 in 2001) based on the quartile measure and a value of 4.74 (from 9.18 in 2001) based on the narrower decile measure. These figures contrast greatly with figures for England and Wales as a whole, where the ratio of high to low quality jobs is in the order of 0.75 , reflecting a slight bias nationally towards employment in low quality jobs. Finally, it is noted that in terms of trends over this time period, that the local index has fallen for the City. This change is a reflection of relatively high volume of job creation at the bottom end of the distribution (however, note than in absolute terms more high quality than lower quality jobs were created in the City). For England and Wales as a whole the index has risen notably reflecting a bias in job creation towards higher quality employment. 
p. 101. Local workplace employment and the quality of jobs framework

Table 2: 2007 APS Estimates of Workplace Employment

\begin{tabular}{|c|c|c|c|c|c|c|c|c|c|c|}
\hline \multicolumn{11}{|c|}{ CITY OF LONDON } \\
\hline SIC & SOC1 & SOC2 & SOC3 & SOC4 & SOC5 & SOC6 & SOC7 & SOC8 & SOC9 & Total \\
\hline$A-B$ & 0 & 0 & 0 & 0 & 0 & 0 & 0 & 0 & 0 & 0 \\
\hline $\mathrm{C}, \mathrm{E}$ & 0 & 2 & 0 & 0 & 0 & 0 & 0 & 0 & 0 & 4 \\
\hline D & 6 & 3 & 8 & 2 & 1 & 0 & 0 & 1 & 2 & 24 \\
\hline $\mathrm{F}$ & 1 & 0 & 2 & 1 & 9 & 0 & 0 & 1 & 2 & 17 \\
\hline G-H & 10 & 0 & 4 & 2 & 4 & 0 & 10 & 0 & 6 & 37 \\
\hline I & 6 & 1 & 4 & 3 & 1 & 2 & 0 & 5 & 1 & 24 \\
\hline $\mathrm{J}-\mathrm{K}$ & 98 & 82 & 82 & 45 & 4 & 0 & 2 & 0 & 11 & 325 \\
\hline L-N & 8 & 14 & 10 & 7 & 0 & 2 & 0 & 0 & 0 & 42 \\
\hline $0-Q$ & 3 & 3 & 6 & 1 & 0 & 2 & 0 & 0 & 1 & 18 \\
\hline Total & 134 & 105 & 116 & 62 & 21 & 7 & 14 & 8 & 23 & 491 \\
\hline \multicolumn{11}{|c|}{ ENGLAND and WALES } \\
\hline SIC & SOC1 & SOC2 & SOC3 & SOC4 & SOC5 & SOC6 & SOC7 & SOC8 & SOC9 & Total \\
\hline$A-B$ & 30 & 18 & 20 & 21 & 84 & 18 & 16 & 21 & 40 & 269 \\
\hline $\mathrm{C}, \mathrm{E}$ & 28 & 31 & 18 & 22 & 23 & 14 & 26 & 18 & 16 & 196 \\
\hline D & 646 & 297 & 369 & 263 & 686 & 48 & 77 & 693 & 286 & 3365 \\
\hline $\mathrm{F}$ & 243 & 118 & 85 & 117 & 1093 & 46 & 47 & 148 & 150 & 2046 \\
\hline G-H & 1038 & 91 & 224 & 349 & 477 & 50 & 1384 & 194 & 1059 & 4865 \\
\hline I & 244 & 88 & 129 & 163 & 83 & 95 & 105 & 528 & 302 & 1737 \\
\hline $\mathrm{J}-\mathrm{K}$ & 980 & 818 & 852 & 859 & 107 & 59 & 170 & 74 & 372 & 4291 \\
\hline L-N & 581 & 1749 & 1616 & 1085 & 104 & 1404 & 60 & 87 & 459 & 7146 \\
\hline O-Q & 200 & 130 & 357 & 166 & 110 & 282 & 62 & 67 & 234 & 1607 \\
\hline Total & 3992 & 3341 & 3670 & 3044 & 2768 & 2016 & 1946 & 1829 & 2917 & 25524 \\
\hline
\end{tabular}


p. 102. Local workplace employment and the quality of jobs framework

Table 3: 2001 Census Counts of Workplace Employment

\begin{tabular}{|c|c|c|c|c|c|c|c|c|c|c|}
\hline \multicolumn{11}{|c|}{ CITY OF LONDON } \\
\hline SIC & SOC1 & SOC2 & SOC3 & SOC4 & SOC5 & SOC6 & SOC7 & SOC8 & SOC9 & $\overline{\text { Total }}$ \\
\hline$A B$ & 0 & 0 & 0 & 0 & 0 & 0 & 0 & 0 & 0 & 0 \\
\hline CDE & 2 & 1 & 2 & 1 & 0 & 0 & 0 & 0 & 0 & 7 \\
\hline$F$ & 1 & 0 & 0 & 0 & 1 & 0 & 0 & 0 & 0 & 3 \\
\hline G & 3 & 1 & 1 & 1 & 0 & 0 & 2 & 0 & 1 & 8 \\
\hline H & 2 & 0 & 0 & 0 & 1 & 0 & 0 & 0 & 2 & 6 \\
\hline I & 4 & 1 & 2 & 2 & 2 & 1 & 0 & 0 & 1 & 13 \\
\hline$J$ & 52 & 14 & 40 & 39 & 1 & 0 & 1 & 1 & 2 & 151 \\
\hline K & 16 & 40 & 16 & 22 & 1 & 0 & 1 & 0 & 3 & 101 \\
\hline L & 1 & 1 & 2 & 3 & 0 & 0 & 0 & 0 & 1 & 8 \\
\hline$M$ & 0 & 2 & 1 & 1 & 0 & 0 & 0 & 0 & 0 & 3 \\
\hline N & 0 & 1 & 1 & 1 & 0 & 0 & 0 & 0 & 0 & 4 \\
\hline OPQ & 2 & 1 & 2 & 1 & 0 & 0 & 0 & 0 & 0 & 8 \\
\hline Total & 83 & 63 & 68 & 71 & 7 & 3 & 5 & 2 & 11 & 312 \\
\hline \multicolumn{11}{|c|}{ ENGLAND and WALES } \\
\hline SIC & soc1 & SOC2 & SOC3 & Soc4 & SOC5 & SOC6 & SOC7 & SOC8 & soc9 & Total \\
\hline$A B$ & 29 & 8 & 6 & 13 & 191 & 14 & 3 & 14 & 80 & 360 \\
\hline CDE & 598 & 258 & 423 & 331 & 753 & 7 & 89 & 909 & 376 & 3745 \\
\hline $\mathrm{F}$ & 173 & 75 & 63 & 109 & 828 & 3 & 14 & 182 & 147 & 1593 \\
\hline G & 861 & 70 & 246 & 342 & 376 & 15 & 1316 & 262 & 482 & 3968 \\
\hline H & 256 & 6 & 24 & 51 & 178 & 31 & 49 & 14 & 512 & 1121 \\
\hline I & 253 & 66 & 124 & 206 & 109 & 106 & 88 & 403 & 287 & 1641 \\
\hline J & 261 & 78 & 249 & 410 & 8 & 4 & 77 & 5 & 21 & 1113 \\
\hline K & 559 & 659 & 551 & 575 & 124 & 52 & 93 & 97 & 342 & 3052 \\
\hline L & 151 & 104 & 452 & 444 & 36 & 36 & 17 & 24 & 74 & 1338 \\
\hline M & 46 & 941 & 139 & 158 & 28 & 318 & 7 & 23 & 168 & 1828 \\
\hline$N$ & 200 & 273 & 700 & 347 & 45 & 796 & 14 & 22 & 154 & 2551 \\
\hline $\mathrm{OPQ}$ & 166 & 86 & 259 & 157 & 62 & 246 & 42 & 45 & 156 & 1218 \\
\hline Total & 3552 & 2624 & 3235 & 3143 & 2738 & 1629 & 1810 & 2000 & 2799 & 23529 \\
\hline
\end{tabular}


p. 103. Local workplace employment and the quality of jobs framework

Table 4: Percentage of jobs which are classified as High Quality

\begin{tabular}{|c|c|c|c|c|c|c|c|c|c|c|c|}
\hline SIC & & $\begin{array}{r}\mathrm{SOC} \\
1\end{array}$ & SOC2 & $\begin{array}{r}\mathrm{SOC} \\
3\end{array}$ & $\begin{array}{r}\text { SOC } \\
4\end{array}$ & $\begin{array}{r}\text { SOC } \\
5\end{array}$ & $\begin{array}{r}\text { SOC } \\
6\end{array}$ & $\begin{array}{r}\text { SOC } \\
7\end{array}$ & $\begin{array}{r}\mathrm{SOC} \\
8\end{array}$ & $\begin{array}{r}\text { SOC } \\
9\end{array}$ & Tota \\
\hline \multirow[t]{2}{*}{$\overline{A-B}$} & $\begin{array}{l}U \\
Q\end{array}$ & 19.2 & $\begin{array}{r}100 . \\
0\end{array}$ & 8.3 & 0.0 & 0.0 & 0.0 & 0.0 & 0.0 & 0.0 & 4.1 \\
\hline & $\begin{array}{l}U \\
D\end{array}$ & 11.5 & 0.0 & 4.2 & 0.0 & 0.0 & 0.0 & 0.0 & 0.0 & 0.0 & 1.4 \\
\hline \multirow[t]{2}{*}{$\mathrm{C}, \mathrm{E}$} & $\begin{array}{l}U \\
Q\end{array}$ & 78.8 & 97.2 & 2.0 & 0.0 & 0.0 & 0.0 & 0.0 & 11.4 & 0.0 & $\begin{array}{r}33 . \\
8\end{array}$ \\
\hline & $\begin{array}{l}U \\
D\end{array}$ & 51.0 & 17.6 & 0.7 & 0.0 & 0.0 & 0.0 & 0.0 & 0.0 & 0.0 & $\begin{array}{r}13 . \\
0\end{array}$ \\
\hline \multirow[t]{2}{*}{ D } & $\begin{array}{l}U \\
Q\end{array}$ & 81.7 & 93.3 & 10.1 & 0.0 & 0.0 & 0.0 & 0.0 & 0.2 & 0.0 & $\begin{array}{r}25 . \\
1\end{array}$ \\
\hline & $\begin{array}{l}U \\
D\end{array}$ & 40.9 & 17.8 & 0.7 & 0.0 & 0.0 & 0.0 & 0.0 & 0.0 & 0.0 & 9.5 \\
\hline \multirow[t]{2}{*}{$F$} & $\begin{array}{l}U \\
Q\end{array}$ & 87.5 & 97.8 & 1.0 & 0.0 & 0.0 & 0.0 & 0.0 & 0.0 & 0.0 & $\begin{array}{r}17 . \\
1\end{array}$ \\
\hline & $\begin{array}{l}U \\
D\end{array}$ & 17.1 & 20.1 & 0.0 & 0.0 & 0.0 & 0.0 & 0.0 & 0.0 & 0.0 & 3.4 \\
\hline \multirow[t]{2}{*}{ G-H } & $\begin{array}{l}U \\
Q\end{array}$ & 20.4 & 99.2 & 2.5 & 0.0 & 0.0 & 0.0 & 0.0 & 0.1 & 0.0 & 5.9 \\
\hline & $\begin{array}{l}U \\
D\end{array}$ & 16.8 & 27.0 & 1.0 & 0.0 & 0.0 & 0.0 & 0.0 & 0.0 & 0.0 & 3.9 \\
\hline \multirow[t]{2}{*}{ I } & $\begin{array}{l}U \\
Q\end{array}$ & 49.6 & 96.4 & 31.3 & 0.0 & 0.0 & 0.0 & 0.0 & 0.2 & 0.0 & $\begin{array}{r}13 . \\
3\end{array}$ \\
\hline & $\begin{array}{l}U \\
D\end{array}$ & 40.8 & 31.9 & 15.6 & 0.0 & 0.0 & 0.0 & 0.0 & 0.0 & 0.0 & 8.2 \\
\hline \multirow[t]{2}{*}{ J-K } & $\begin{array}{l}U \\
Q\end{array}$ & 81.6 & 97.8 & 9.0 & 0.0 & 0.0 & 0.0 & 0.0 & 0.0 & 0.0 & $\begin{array}{r}39 . \\
1\end{array}$ \\
\hline & $\begin{array}{l}U \\
D\end{array}$ & 65.0 & 51.0 & 5.6 & 0.0 & 0.0 & 0.0 & 0.0 & 0.0 & 0.0 & $\begin{array}{r}25 . \\
5\end{array}$ \\
\hline \multirow[t]{2}{*}{ L-N } & $\begin{array}{l}U \\
Q\end{array}$ & 67.4 & 94.4 & 25.6 & 0.0 & 0.0 & 0.0 & 0.0 & 0.8 & 0.0 & $\begin{array}{r}33 . \\
8\end{array}$ \\
\hline & $\begin{array}{l}U \\
D\end{array}$ & 36.9 & 44.1 & 1.6 & 0.0 & 0.0 & 0.0 & 0.0 & 0.0 & 0.0 & $\begin{array}{r}13 . \\
9\end{array}$ \\
\hline \multirow[t]{2}{*}{$\mathrm{O}-\mathrm{Q}$} & $\begin{array}{l}U \\
Q\end{array}$ & 36.6 & 46.0 & 38.8 & 0.0 & 0.0 & 0.0 & 0.0 & 0.8 & 0.0 & $\begin{array}{r}16 . \\
2\end{array}$ \\
\hline & $\begin{array}{l}U \\
D\end{array}$ & 27.7 & 13.1 & 7.0 & 0.0 & 0.0 & 0.0 & 0.0 & 0.0 & 0.0 & 5.9 \\
\hline \multirow[t]{2}{*}{$\begin{array}{l}\text { Tota } \\
\text { I }\end{array}$} & $\begin{array}{l}U \\
Q\end{array}$ & 59.3 & 93.7 & 19.7 & 0.0 & 0.0 & 0.0 & 0.0 & 0.4 & 0.0 & $\begin{array}{r}24 . \\
1\end{array}$ \\
\hline & $\begin{array}{l}U \\
D \\
\end{array}$ & 37.2 & 40.4 & 3.2 & 0.0 & 0.0 & 0.0 & 0.0 & 0.0 & 0.0 & $\begin{array}{r}11 . \\
4\end{array}$ \\
\hline
\end{tabular}


p. 104. Local workplace employment and the quality of jobs framework

Table 4B: Percentage of jobs which are classified as High Quality (additional detail)

\begin{tabular}{|c|c|c|c|c|c|c|c|c|c|c|c|}
\hline SIC & & $\begin{array}{l}\text { SOC } \\
1\end{array}$ & SOC2 & $\begin{array}{l}\text { SOC } \\
3\end{array}$ & $\begin{array}{l}\text { SOC } \\
4\end{array}$ & $\begin{array}{l}\text { SOC } \\
5\end{array}$ & $\begin{array}{l}\text { SOC } \\
6\end{array}$ & $\begin{array}{l}\text { SOC } \\
7\end{array}$ & $\begin{array}{l}\text { SOC } \\
8\end{array}$ & $\begin{array}{l}\text { SOC } \\
9\end{array}$ & $\begin{array}{l}\text { Tota } \\
\text { I }\end{array}$ \\
\hline $\begin{array}{l}\text { CD } \\
\text {. }\end{array}$ & $U$ & 81.4 & 93.8 & 9.4 & 0.0 & 0.0 & 0.0 & 0.0 & 0.7 & 0.0 & 25.7 \\
\hline \multirow[t]{2}{*}{$\mathrm{E}$} & $Q$ & & & & & & & & & & \\
\hline & $\begin{array}{l}U \\
D\end{array}$ & 41.7 & 17.7 & 0.7 & 0.0 & 0.0 & 0.0 & 0.0 & 0.0 & 0.0 & 9.7 \\
\hline \multirow[t]{2}{*}{$\mathbf{G}$} & $\begin{array}{l}U \\
Q\end{array}$ & 23.3 & 99.2 & 1.4 & 0.0 & 0.0 & 0.0 & 0.0 & 0.1 & 0.0 & 6.7 \\
\hline & $\begin{array}{l}U \\
D\end{array}$ & 19.5 & 24.6 & 1.0 & 0.0 & 0.0 & 0.0 & 0.0 & 0.0 & 0.0 & 4.4 \\
\hline \multirow[t]{2}{*}{ H } & $\begin{array}{l}U \\
0\end{array}$ & 9.8 & $\begin{array}{r}100 . \\
0\end{array}$ & 18.8 & 0.0 & 0.0 & 0.0 & 0.0 & 0.0 & 0.0 & 2.8 \\
\hline & $\begin{array}{l}U \\
D\end{array}$ & 7.2 & 54.8 & 0.0 & 0.0 & 0.0 & 0.0 & 0.0 & 0.0 & 0.0 & 1.8 \\
\hline \multirow[t]{2}{*}{ J } & $\begin{array}{l}U \\
Q\end{array}$ & 89.3 & 98.3 & 15.7 & 0.0 & 0.0 & 0.0 & 0.0 & 0.0 & 0.0 & 35.7 \\
\hline & $\begin{array}{l}U \\
D\end{array}$ & 86.3 & 50.3 & 14.7 & 0.0 & 0.0 & 0.0 & 0.0 & 0.0 & 0.0 & 30.3 \\
\hline \multirow[t]{2}{*}{ K } & $\begin{array}{l}U \\
Q\end{array}$ & 78.2 & 97.7 & 5.9 & 0.0 & 0.0 & 0.0 & 0.0 & 0.0 & 0.0 & 40.4 \\
\hline & $\begin{array}{l}U \\
D\end{array}$ & 55.3 & 51.1 & 1.5 & 0.0 & 0.0 & 0.0 & 0.0 & 0.0 & 0.0 & 23.8 \\
\hline \multirow[t]{2}{*}{ L } & $\begin{array}{l}U \\
Q\end{array}$ & 83.2 & 92.6 & 39.9 & 0.0 & 0.0 & 0.0 & 0.0 & 1.1 & 0.0 & 34.5 \\
\hline & $\begin{array}{l}U \\
D\end{array}$ & 54.3 & 40.7 & 1.0 & 0.0 & 0.0 & 0.0 & 0.0 & 0.0 & 0.0 & 11.8 \\
\hline \multirow[t]{2}{*}{ M } & $\begin{array}{l}U \\
Q\end{array}$ & 55.0 & 94.3 & 7.5 & 0.0 & 0.0 & 0.0 & 0.0 & 0.0 & 0.0 & 49.3 \\
\hline & $\begin{array}{l}U \\
D\end{array}$ & 43.5 & 41.3 & 1.0 & 0.0 & 0.0 & 0.0 & 0.0 & 0.0 & 0.0 & 22.1 \\
\hline \multirow[t]{2}{*}{$N$} & $\begin{array}{l}U \\
Q\end{array}$ & 58.7 & 95.9 & 19.2 & 0.0 & 0.0 & 0.0 & 0.0 & 1.7 & 0.0 & 21.7 \\
\hline & $\begin{array}{l}U \\
D\end{array}$ & 21.3 & 55.4 & 2.1 & 0.0 & 0.0 & 0.0 & 0.0 & 0.0 & 0.0 & 8.9 \\
\hline
\end{tabular}


p. 105. Local workplace employment and the quality of jobs framework

Table 5: Percentage of jobs which are classified as Low Quality

\begin{tabular}{llrrrrrrrrrr}
\hline SIC & & SOC1 & SOC2 & SOC3 & SOC4 & SOC5 & SOC6 & SOC7 & SOC8 & SOC9 & All \\
\hline A-B & $L Q$ & 0.0 & 0.0 & 0.0 & 2.3 & 98.0 & 98.9 & 90.5 & 70.6 & 98.7 & 77.4 \\
& $L D$ & 0.0 & 0.0 & 0.0 & 0.0 & 0.3 & 96.6 & 66.7 & 5.9 & 75.5 & 19.9 \\
C,E & $L Q$ & 0.0 & 0.0 & 0.0 & 8.5 & 2.0 & 75.0 & 69.9 & 10.8 & 65.7 & 11.0 \\
& $L D$ & 0.0 & 0.0 & 0.0 & 0.0 & 1.5 & 25.0 & 2.7 & 5.4 & 28.6 & 2.1 \\
D & $L Q$ & 0.1 & 0.0 & 0.7 & 16.1 & 7.6 & 91.7 & 69.7 & 44.1 & 71.2 & 20.3 \\
& LD & 0.0 & 0.0 & 0.0 & 0.0 & 3.5 & 44.4 & 23.3 & 5.2 & 36.0 & 5.5 \\
F & $L Q$ & 0.0 & 0.0 & 0.0 & 6.1 & 0.3 & 91.7 & 57.4 & 8.0 & 84.3 & 9.1 \\
& LD & 0.0 & 0.0 & 0.0 & 0.0 & 0.0 & 8.3 & 23.5 & 0.5 & 3.8 & 0.6 \\
G-H & $L Q$ & 3.1 & 0.3 & 9.0 & 24.6 & 40.1 & 97.1 & 96.3 & 66.3 & 97.3 & 59.7 \\
& LD & 0.0 & 0.0 & 0.0 & 0.0 & 32.9 & 79.6 & 87.6 & 7.9 & 81.3 & 47.4 \\
I & $L Q$ & 0.0 & 0.0 & 0.0 & 10.2 & 4.3 & 54.7 & 82.9 & 60.2 & 48.1 & 35.4 \\
& $L D$ & 0.0 & 0.0 & 0.0 & 0.0 & 1.8 & 10.0 & 9.2 & 26.6 & 11.9 & 11.4 \\
J-K & $L Q$ & 0.0 & 0.0 & 0.1 & 6.5 & 10.1 & 85.6 & 61.9 & 47.7 & 88.4 & 13.8 \\
& $L D$ & 0.0 & 0.0 & 0.0 & 0.0 & 3.2 & 16.1 & 6.8 & 14.9 & 55.7 & 5.7 \\
L-N & $L Q$ & 0.1 & 0.2 & 0.6 & 16.5 & 62.0 & 85.8 & 86.5 & 38.0 & 96.4 & 28.6 \\
& $L D$ & 0.0 & 0.0 & 0.0 & 0.0 & 49.6 & 10.7 & 17.7 & 9.7 & 81.9 & 8.4 \\
O-Q & $L Q$ & 3.2 & 34.0 & 6.5 & 15.7 & 78.5 & 95.8 & 84.5 & 30.5 & 95.0 & 48.4 \\
& $L D$ & 0.0 & 0.0 & 0.0 & 0.0 & 6.3 & 86.6 & 46.5 & 11.7 & 72.2 & 30.2 \\
All & $L Q$ & 1.0 & 1.4 & 1.6 & 13.9 & 21.2 & 86.1 & 90.5 & 47.0 & 87.3 & 31.8 \\
& $L D$ & 0.0 & 0.0 & 0.0 & 0.0 & 8.7 & 23.8 & 70.6 & 11.7 & 60.9 & 16.1 \\
\hline
\end{tabular}


p. 106. Local workplace employment and the quality of jobs framework

Table 5B: Percentage of jobs which are classified as Low Quality (additional detail)

\begin{tabular}{llrrrrrrrrrr}
\hline SIC & & SOC1 & SOC2 & SOC3 & SOC4 & SOC5 & SOC6 & SOC7 & SOC8 & SOC9 & \multicolumn{1}{c}{ All } \\
\hline CDE & $L Q$ & 0.1 & 0.0 & 0.6 & 15.4 & 7.3 & 90.0 & 69.8 & 42.6 & 71.1 & 19.6 \\
& $L D$ & 0.0 & 0.0 & 0.0 & 0.0 & 3.4 & 42.5 & 18.1 & 5.2 & 35.8 & 5.3 \\
$\mathbf{G}$ & $L Q$ & 0.1 & 0.3 & 9.6 & 21.9 & 15.7 & 96.6 & 96.3 & 65.0 & 94.6 & 55.0 \\
& $L D$ & 0.0 & 0.0 & 0.0 & 0.0 & 6.6 & 75.9 & 87.9 & 8.3 & 59.9 & 41.7 \\
$\mathbf{H}$ & $L Q$ & 13.9 & 0.0 & 0.0 & 42.7 & 96.5 & 97.2 & 95.7 & 79.4 & 99.3 & 76.5 \\
& $L D$ & 0.0 & 0.0 & 0.0 & 0.0 & 94.0 & 80.6 & 78.1 & 4.1 & 97.6 & 68.0 \\
$\mathrm{~J}$ & $L Q$ & 0.0 & 0.0 & 0.0 & 1.6 & 25.0 & 60.0 & 75.4 & 50.0 & 75.0 & 8.8 \\
& $L D$ & 0.0 & 0.0 & 0.0 & 0.0 & 15.0 & 20.0 & 2.8 & 25.0 & 23.6 & 0.7 \\
$\mathbf{K}$ & $L Q$ & 0.0 & 0.0 & 0.2 & 9.8 & 9.5 & 86.4 & 46.9 & 47.6 & 89.0 & 15.6 \\
& $L D$ & 0.0 & 0.0 & 0.0 & 0.0 & 2.7 & 16.0 & 11.3 & 14.4 & 57.2 & 7.5 \\
$\mathrm{~L}$ & $L Q$ & 0.1 & 0.4 & 0.0 & 4.1 & 28.3 & 85.6 & 90.2 & 38.0 & 86.1 & 10.0 \\
& $L D$ & 0.0 & 0.0 & 0.0 & 0.0 & 15.0 & 14.4 & 3.8 & 15.2 & 50.6 & 3.2 \\
$\mathbf{M}$ & $L Q$ & 0.0 & 0.1 & 0.9 & 36.2 & 81.0 & 99.3 & 84.0 & 12.0 & 98.8 & 33.2 \\
& $L D$ & 0.0 & 0.0 & 0.0 & 0.0 & 64.7 & 5.4 & 40.0 & 1.6 & 94.6 & 10.9 \\
$\mathbf{N}$ & $L Q$ & 0.1 & 0.6 & 1.0 & 24.3 & 74.5 & 79.4 & 81.3 & 79.3 & 98.1 & 35.5 \\
& $L D$ & 0.0 & 0.0 & 0.0 & 0.0 & 65.1 & 13.0 & 33.8 & 18.1 & 79.9 & 9.5 \\
\hline
\end{tabular}

Table 6: Quality of Job Summaries for City of London and England and Wales

\begin{tabular}{lrrrr}
\hline & & City of London & \multicolumn{2}{r}{ England and Wales } \\
\hline Workplace jobs & $\mathbf{2 0 0 1}$ & $\mathbf{2 0 0 7}$ & $\mathbf{2 0 0 1}$ & $\mathbf{2 0 0 7}$ \\
& 312,200 & 490,000 & $23,528,900$ & $25,523,600$ \\
Quartile based measure & & & & \\
HQ Jobs & 136,700 & 213,600 & $5,055,700$ & $6,214,500$ \\
LQ Jobs & 23,300 & 52,400 & $7,524,300$ & $7,956,100$ \\
Local Index $(\boldsymbol{\theta})$ & 5.87 & 4.08 & 0.67 & 0.78 \\
& & & & \\
Decile based measure & & & & \\
HQ Jobs & 95,500 & 130,300 & $2,476,500$ & $2,970,800$ \\
LQ Jobs & 10,400 & 27,500 & $3,819,900$ & $4,072,300$ \\
Local Index $(\theta)$ & 9.18 & 4.74 & 0.65 & 0.73 \\
\hline Note: Job estimates are presented rounded to the nearest hundred.
\end{tabular}

Note: Job estimates are presented rounded to the nearest hundred. 
p. 107. Local workplace employment and the quality of jobs framework

\section{Conclusion}

This paper has introduced the quality of jobs framework and discussed and illustrated its application to local workplace employment data. It is suggested that the methodology, which has evolved in the economics literature, is potentially both relevant and useful in providing a means of comparing local economies and measuring their trajectories over time. In particular, the framework can supplement or be used in place of GVA based measures for which data is more limited, both on a geographical basis and over time. It is also argued that quality of jobs measures are superior to GVA in that they are not distorted by differences in income and/or purchasing power at the local area level. In this respect, the methodology suggested in this paper, whilst still evolving, has much potential for future application. Avenues for further research include the application of job quality data to examine spatial inequalities in aspects of economic growth and the extent of economic recovery at local area level in the context of the move from a post industrial economy to a knowledge based economy.

* Correspondence Address: Paul Jones, Development and Society, Sheffield Hallam University, Norfolk Building, Room 209, Howard Street, Sheffield, S1 1WB. Email: p.jones@shu.ac.uk.

\section{References}

Acemoglu, D. (2001) Higher level jobs versus Lower level jobs. Journal of Labor Economics, 19, 1, 1-21.

Acemoglu, D. (1999) Changes in Unemployment and Wage Inequality: An Alternative Theory and Some Evidence. American Economic Review, American Economic Association, 89, 5, 1259-1278.

Athey, G., Lucci, P. and Webber, C. (2007) Two-track cities: The challenge of sustaining growth and building opportunity. Institute for Public Policy Research Discussion Paper 11. London: IPPR.

Autor, D.H., Levy, F. and Murnane, R.J. (2003) The Skill Content of Recent Technological Change: An Empirical Exploration. Quarterly Journal of Economics, $118,4,1279-1333$.

Beatty, C. and Fothergill, S. (2004) Economic Change and the Labour Market in Britain's Seaside Towns. Regional Studies, 38, 5, 459-478.

Beatty, C., Fothergill, S. and Powell, R. (2007) Twenty years on: has the economy of the UK coalfields recovered? Environment and Planning A, 39, 1654-1675.

Costrell, R.M. (1990) Methodology in the "Job Quality" Debate. Industrial Relations, XXIX, 94-110.

Cutler, D.M., Lleras-Muney, A. and Vogl, T. (2008) Socioeconomic Status and Health: Dimensions and Mechanisms. NBER Working Papers 14333, National Bureau of Economic Research.

Davis, S.J., Haltiwanger, J.C. and Schuh, S. (1996) Job Creation and Destruction. MIT Press.

Erdem, E., and Glyn, A. (2001) Job deficits in UK regions. Oxford Bulletin of Economics and Statistics, 63 SI, 737-752.

Fothergill, S. (2001) The true scale of the regional problem in the UK. Regional Studies, $35,241-246$.

Freud, D. (2007) The Freud Review: Reducing dependency, increasing opportunity: options for the future of welfare to work. London: Department for Work and Pensions. 
Gittleman, M.B. and Howell, D.R. (1995) Changes in the Structure and Quality of Jobs in the United States: Effects by Race and Gender, 1973-1990. Industrial and Labor Relations Review, XLVIII, 420-440.

Goos, M. and Manning, A. (2007) Lousy and lovely jobs: the rising polarization of work in Britain. Review of Economics and Statistics, 89, 118-133.

Green, A. and Owen, D. (1998) Where are the Jobless? Changing unemployment and non-employment in cities and regions. Bristol: Policy Press.

Green, A.E. (1999) Insights into unemployment and non-employment in Europe using alternative measures. Regional Studies, 33, 453-64.

Harker, L. (2006) Delivering on Child Poverty: what would it take? London: Department for Work and Pensions.

Hepworth, M., Binks, J. and Ziemann, B. (2005) Regional Employment and Skills in the Knowledge Economy. London: UK Department of Trade and Industry (DTI).

HM Treasury (2003) Productivity in the UK: 4 - The Local Dimension. London: HM Treasury.

Ilg, R. E. (1996) The nature of employment growth, 1989-1995. Monthly Labour Review, CXIX, 29-36.

Jencks, C., Perman, L. and Rainwaler, L. (1988) What Is a Goodjob? A New Measure of Labor-Market Success. American Journal of Sociology, 93, 6 1322-57.

Jones, P.S. and Dickerson, A.P. (2007) Poor returns: winners and losers in the job market. Equal Opportunities Commission (EOC) Working paper Series No. 52. Spring 2007.

Jones, P.S. and Green, A.E. (2009, forthcoming) The Quantity and Quality of Jobs: Changes in UK Regions, 1997-2007. Environment and Planning A.

Kaplanis, I. (2007) The geography of employment polarisation in Britain. London: IPPR.

Lahr, M. (2004) Biproportional Techniques in Input-Output Analysis: Table Updating and Structural Analysis. Economic Systems Research, 16, 2, 115-134.

Leitch, S. (2006) Prosperity for all in the global economy - world class skills. London: HM Treasury.

Leunig, T. and Swaffield, J. (2008) Cities Unlimited. London: Policy Exchange.

Martins, P.S. (2004) Industry wage Premia: evidence from the wage distribution. Economics Letters, 83, 157-163.

Massey, D. (1984) Spatial Divisions of Labour. London: Macmillan.

Meisenheimer, J.R. II (1998) The services industry in the 'good' versus 'bad' jobs debate. Monthly Labour Review, February 1998, 22-47.

OECD (2001) The Characteristics and Quality of Service Sector Jobs. OECD Employment Outlook, 2001, 89-128.

ONS (2003) Jobs densities for local areas: a new indicator. Labour Market Trends. August Edition. London: Office for National Statistics, HMSO.

Piore, M. (1975) Notes for a Theory of Labor Market Stratification, In: Richard C. Edwards, Michael Reich, and David M. Gordon, Eds. Labour Market Segmentation. Lexington, Mass.: D, C. Heaih.

Sen, A. (1998) Mortality as an Indicator of Economic Success and Failure. Economic Journal, 108, 446, 1-25.

Stone, R. (1961) Input-Output and National Accounts. Paris: Organization for European Economic Cooperation.

Turok, I. and Edge, N. (1999) The Jobs Gap in Britain's Cities. Bristol: Policy Press. 